Discussion Paper No. 966

\title{
A CHOICE EXPERIMENT \\ ON TAXES: \\ ARE INCOME AND CONSUMPTION \\ TAXES EQUIVALENT?
}

\author{
Hirofumi Kurokawa \\ Tomoharu Mori \\ Fumio Ohtake
}

March 2016

The Institute of Social and Economic Research

Osaka University

6-1 Mihogaoka, Ibaraki, Osaka 567-0047, Japan 


\title{
A Choice Experiment on Tax: Are Income and Consumption Taxes Equivalent?*
}

\author{
Hirofumi Kurokawa $^{\mathrm{a}} \quad$ Tomoharu Mori $^{\mathrm{b}} \quad$ Fumio Ohtake $^{\mathrm{c}}$
}

March 28, 2016

\begin{abstract}
We test the equivalence of income and consumption taxes through a choice experiment. Under a given set of income and consumption parameters, subjects were asked to choose among an income tax of $20 \%$, a consumption tax of $25 \%$ (which is an equivalent tax burden), a consumption tax of $22 \%$, and a consumption tax of $20 \%$. Our results showed that subjects prefer income tax to consumption tax when the nominal consumption tax rate is higher than the nominal income tax rate. However, subjects tend to prefer consumption tax to income tax when the nominal tax rates are identical. Our result, that subjects prefer income tax to consumption tax despite a higher tax burden, implies the consumption tax miscalculation bias. The consumption tax miscalculation bias is one where subjects miscalculate the amount of consumption tax as if it is declared by tax inclusive, as in the case of income tax, despite consumption tax being tax exclusive. If the income tax burden is equivalent to the consumption tax burden, subjects prefer income tax. This result implies that income and consumption taxes are not equivalent due to the consumption tax miscalculation bias.
\end{abstract}

JEL classification: H24, C91

Keywords: Tax equivalence, Income tax, Consumption tax, Misperception of tax, Behavioral and experimental economics

\footnotetext{
* We are grateful to Hidehiko Ichimura, Keigo Kameda, Akihiro Kawase, Daiji Kawaguchi, Yukinobu Kitamura, Yutaka Kayaba, Daigo Nakata, Shuichiro Sasaki, Kan Takeuchi, Yosuke Tada, Yosuke Yasuda, and seminar participants at Chulalongkorn University, Meiji University, the 72nd annual meeting of the Japan Institute of Public Finance, the 10th Applied Econometrics Conference, the 19th annual meeting of the Japan Public Choice Society, the 9th annual meeting of the Association of Behavioral Economics and Finance, the 93rd meeting of OEIO for their comments. Any remaining errors are ours. Our gratitude goes to the Japan Society for the Promotion of Science and the Institute of Social and Economic Research at Osaka University for financial supports. JSPS Grant Numbers are, $13 J 05272$ (H., Kurokawa), and 15K17083 (T., Mori), (A) 26245041 (F., Ohtake).

a Graduate School of Economics, Osaka University and Research fellow of JSPS. E-mail addresses: nge007kh@student.econ.osaka-u.ac.jp

b The Research Institute for Socionetwork Strategies, Kansai University. E-mail: r148033@kansai-u.ac.jp c Institute of Social and Economic Research, Osaka University. E-mail address: ohtake@iser.osaka-u.ac.jp
} 


\section{Introduction}

It is well known that consumption tax is equivalent to labor income tax in the public finance literature. These taxes are theoretically equivalent taxes because the budget constrain with consumption tax coincides with that with income tax. However, Blumkin et al. (2012) showed that these taxes are not equivalent in a real-effort experiment. ${ }^{1}$ In their experiment, subjects reduce their effort more in response to income tax than to equivalent consumption tax. This result implies that people behave differently when confronted with one tax than when confronted with the other tax even though these taxes are substantially equivalent.

Such an irrational behavior is observed by a field experiment, an empirical study, and a laboratory experiment. Chetty et al. (2009) showed that, in comparison with tax-exclusive price tags, tax-inclusive price tags reduce sales by $8 \% .{ }^{2}$ Finkelstein (2009) showed that the introduction of electronic toll collection led to a reduced sense of financial burden and resulted in an increase in toll fare. Moreover, some field experiments tested whether people behave differently when they get information or advice about tax systems and benefits (Bettinger et al. 2012; Chetty and Saez 2013; Liebman and Luttmer 2011).

The misperception of taxes shown in Blumkin et al. (2012) and Chetty et al. (2009) results from ignorance about consumption tax. In the study of Blumkin et al. (2012), subjects reduce effort under income tax, because their nominal earnings decrease and they cognize the income tax. On the other hand, under consumption tax, subjects provide effort without considering the existence of the consumption tax. Therefore, we can propose that the reason income and consumption taxes are not equivalent is the consumption tax "ignorance bias." In Chetty et al.'s (2009) study, consumers buy many more goods when price tags are tax-exclusive than when they are tax-inclusive. This is because consumers ignore the consumption tax when goods are posted tax-exclusive price tags. The ignorance of this tax results in irrational behavior.

The misperception of taxes results from the miscalculation of taxes even when people take into consideration the existence of taxes. For example, some research points to the confusion between average and marginal income tax rates (de Bartolome 1995; Liebman and Zackhauser 2004; Feldman and Katušćák (2006). Abeler and Jager (2015) showed that subjects cannot behave optimally in a complex progressive income tax system, but can behave optimally in a

\footnotetext{
${ }^{1}$ Although there is no other experimental study that tests the equivalence of income and consumption taxes, there are some experimental studies that test the tax incidence equivalence. This means the burden of a tax on buyers and sellers is independent of who actually pays the tax. The tax incidence equivalence holds in a simple market (Kachelmeier et al. 1994; Borck et al. 2002; Ruffle 2005). However, it does not hold in an ultimatum game (Kerschbamer and Kirchsteiger 2000) and voting (Sausgruber and Tyran 2005, 2011).

${ }_{2}^{2}$ Feldman and Ruffle (2015) showed a similar result in a laboratory experiment. Their subjects spend more under tax-exclusive prices while total purchases under tax-inclusive and tax-rebate prices are not different.
} 
simple progressive income tax system. We can interpret this as the income tax "miscalculation bias” leads to a misperception of taxes.

According to the results of Blumkin et al. (2012), we can deduce that the equivalence between income and consumption taxes holds if people can properly take into consideration the existence of consumption tax. However, previous research shows that the miscalculation of income tax also results in the misperception of tax. Thus, even if people take into consideration consumption tax, the equivalence between income and consumption taxes might not hold if people miscalculate the tax burden from either tax. For example, it is likely that many people misperceive consumption tax being equivalent to income tax when the tax rates are the same. ${ }^{3}$ Assuming that all income is spent on consumer goods, if total income is $\$ 1$ million and the income tax rate is $10 \%$, the amount of tax is $\$ 100$ thousand. If the consumption tax rate is $10 \%$, people often misunderstand it as being imposed on the amount of goods that already include tax and believe that the amount of tax would be $\$ 100$ thousand, though the correct amount of tax would be $\$ 91$ thousand. ${ }^{4}$ Because people do not correctly understand that the way income tax is applied is different from the way consumption tax is applied, people might not understand that the amount of income tax is not equivalent to the amount of consumption tax when all income spent on consumer goods and the income and consumption tax rates are the same. In other words, consumption and income taxes might not be equivalent because of the consumption tax miscalculation bias.

In Blumkin et al.'s (2012) study, the consumption tax ignorance bias is one of the explanations why income and consumption taxes are not seen as equivalent and subjects prefer consumption tax to income tax. Another explanation is that their incomes are determined by the performance of real-effort task. Durante et al. (2014) showed that subjects choose a lower income tax rate when their incomes are determined by effort than when their incomes are determined by luck. This result implies that subjects do not strongly prefer income tax when their incomes are determined by a real-effort than when their incomes are determined randomly. Therefore, subjects might tend not to prefer income tax, when their incomes are determined randomly, and in these cases, income and consumption taxes are equivalent.

Our research question is whether income and consumption taxes are equivalent. If the equivalence does not hold, we can identify the following reason: Consumption tax ignorance bias, consumption tax miscalculation bias, or income determination. In Blumkin et al.ss (2012)

\footnotetext{
3 We define the income tax rate as $t_{y}$ and the consumption tax rate as $t_{c}$. When all income is spent on consumption goods, the income tax rate that brings in the same amount of consumption tax is $t_{y}=$ $t_{c} /\left(1+t_{c}\right)<t_{c}$. The consumption tax rate that brings in the same amount of income tax is smaller than the income tax rate because the denomination of the consumption tax is larger than the income tax.

4 Consumption tax is imposed on the before-tax price ( $\$ 909$ thousand in this case).
} 
study, subjects endogenously determine their incomes and consumption under a given tax system. In this paper, subjects choose a tax system under a set of given income and consumption assumptions. Given an income distribution and the assumption that subjects consume all income, subjects choose a preferable tax system from two options. The set of two options includes three types: a $20 \%$ income tax and a $25 \%$ consumption tax, a $20 \%$ income tax and a $22 \%$ consumption tax, and a $20 \%$ income tax and a $20 \%$ consumption tax. ${ }^{5}$ The first set of two options is revenue neutral and the others are not revenue neutral. One tax choice for each subject is randomly selected and the choice is imposed on his or her payment. The sequence of the experiment is as follows: First, subjects choose tax systems before their incomes are determined. Second, their incomes are determined randomly or on the basis of their performance in a real-effort task. Third, subjects choose tax systems again. Fourth, subjects solve computational questions about cognitive reflection test (CRT; Frederick 2005) and the amount of income and consumption taxes. Finally, the imposed tax system is determined.

Our main findings are as follows: First, when the tax burden is equivalent, subjects prefer the $20 \%$ income tax to the $25 \%$ consumption tax. Second, subjects prefer the $20 \%$ income tax to the $22 \%$ consumption taxes, even though the $22 \%$ consumption taxes are a lesser burden than the $20 \%$ income tax. Third, when the tax rates are the same, $20 \%$, subjects prefer the $20 \%$ consumption tax, which is a lesser burden than the $20 \%$ income tax. Fourth, subjects tend to prefer consumption tax to income tax when their incomes are determined by a real-effort than when their incomes are determined randomly.

The equivalence between income and consumption taxes isn't hold by the consumption tax miscalculation bias, because subjects prefer the $20 \%$ income tax to the $25 \%$ consumption tax. Subjects calculate the tax burden of a consumption tax in the same way as an income tax. Subjects do not prefer consumption tax, which has a higher nominal rate than income tax. Hence, subjects evaluate the tax systems not on the real tax burden but on the nominal tax rate. Furthermore, even when the financial burden of consumption tax is smaller than the financial burden of income tax, subjects prefer the $20 \%$ income tax to the $22 \%$ consumption taxes because the nominal consumption tax rate is higher than the nominal income tax rate. In this situation, subjects feel a larger financial burden from consumption tax. When the nominal consumption tax rate is identical to the nominal income tax rate, subjects feel the same burden

\footnotetext{
${ }^{5}$ It seems that the consumption tax (20-25\%) that we use in the experiment is higher than the consumption rate (8\%) that is imposed on consumption goods at the time of conducting the experiment in Japan. However, the experimental consumption tax rate is not a high enough consumption tax in Europe. Furthermore, Braun and Joines (2015) showed that if the government of Japan corrected fiscal imbalances using only an increase in the consumption tax, the consumption tax rate needs to gradually rise to $46 \%$ in 2100 and then eventually fall to $36.37 \%$. Therefore, the consumption tax (20-25\%) is important for Japan in the future.
} 
for both these taxes and do not prefer income tax if the amount of tax is equivalent. This result is consistent with that of Blumkin et al. (2012) under the tax rate illusion.

We also find that only one-third of the subjects evaluate the tax system based on the tax burden. One-third of the subjects, who are supposed to prefer a consumption tax over an income tax if tax owed is equivalent, prefer the $20 \%$ income tax to the $25 \%$ consumption tax. They are consumption tax miscalculation-biased subjects. One-third of the subjects prefer an income tax independent of tax rates. The result that subjects prefer the $20 \%$ income tax to the $25 \%$ consumption tax implies that they seemingly prefer an income tax to a consumption tax when income and consumption taxes are equivalent. However, if we regard the miscalculation biased as subjects who prefer a consumption tax when these taxes are equivalent, the proportion preferring an income tax nearly equals that preferring a consumption tax.

Our result implies that one of the origins of tax misperception is the fact that people incorrectly understand the definition of tax. Many people miscalculate the amount of consumption tax because they misunderstand that consumption tax is declared by tax inclusive, as in the case of income tax, despite consumption tax being tax exclusive. If we standardize all taxes as being tax inclusive, people can correctly calculate the amount of taxes and make unbiased decisions. Even if people consider the existence of taxes, they are likely to miscalculate the amount of tax. Taxes should be presented in ways that are difficult to miscalculate.

The remainder of the paper is organized as follows: Section 2 describes the experimental design, and section 3 explains the hypothesis. We present experimental results in section 4 . Section 5 discusses results and presents conclusions.

\section{Experimental Design}

We conducted the experiment in December 2015 with 105 student subjects at Osaka University. We conducted four sessions: Each session involved 25, 28, 25, and 27 subjects. The average duration of the experiment was 60 minutes. The average payment per subject was $¥ 2,767$ (approximately USD 22 at the time of the experiment). The experiment was programmed and conducted using z-Tree (Fischbacher 2007).

In the experiment, subjects chose a preferable tax system from two tax systems, given an income distribution and the assumption that subjects consume all income. Figure 1 shows the sequence of our experiment. After reading the instructions, subjects chose between two tax systems three times before their incomes were determined. After subjects chose the tax system, their incomes were determined and then they again chose a tax system between two options. After the tax choices, subjects solved computational questions. Finally, if subjects completed the exit survey, one tax choice for each subject was randomly selected and the total consumption 
was converted into his or her payment under the tax choice. ${ }^{6}$

We define income distribution as $\{1600,2200,2500,3100$, and 4500 points $\}$. The number of subjects for each income level was designed to be even by each session. We assumed that subjects consume all income. The set of tax systems is as follows:

1) A $20 \%$ income tax or a $25 \%$ consumption tax

2) A $20 \%$ income tax or a $22 \%$ consumption tax

3) A $20 \%$ income tax or a $20 \%$ consumption tax

The time restriction before their incomes were determined was 120 seconds and that after their incomes were determined was 60 seconds. The before-tax income and consumption is displayed in the second tax choice.

Table 1 shows the after-tax income and consumption. We explained that income tax is a tax in proportion to income. When we define an income as $Y$ and the income tax rate as $t_{y}$, the amount of tax is $t_{y} Y$. For example, if the income tax rate is $20 \%$, the amount of tax for the first quintile is $320(=0.2 \times 1600)$. We explained that consumption tax is a tax in proportion to consumption and the tax-inclusive amount of consumption does not change even if the consumption tax is imposed; the net (substantial) consumption subtracts the amount of tax from the consumption in responding to the income. When we define consumption including tax as $C G$ and the consumption tax rate as $t_{c}$, the amount of tax is $\left(t_{c} /\left(1+t_{c}\right)\right) C G$. For example, if the consumption tax rate is $25 \%$, the amount of tax for the first quintile is 320 $(=(0.25 /(1+0.25)) \times 1600)$.

The provisional incomes were assigned to subjects in two possible ways: randomly (henceforth "Random") or on the basis of their relative performance in a real-effort task (henceforth "Real-effort"). ${ }^{7}$ These two methods were designed to mimic some determinants of economic success in real life. ${ }^{8}$ Random mimics luck and Real-effort mimics hard work. We use a slider task (Gill and Prowse 2012) as a Real-effort task. ${ }^{9}$ Figure 2 shows the screen of a slider task. There are 48 sliders positioned at 0 at the first time. By using the mouse, subjects adjusted the slider to position it at 50 as much as possible. The time given to do this was 120 seconds. After the first tax choice task, subjects practiced the slider task twice. After the practice,

\footnotetext{
6 We converted 1 point into $¥ 1$.

753 subjects were assigned to Random and 52 subjects were assigned to Real-effort income groups.

8 Other determinants are family background, acquired knowledge, and ability (Durante et al. 2014).

${ }^{9}$ Gill and Prowse (2011) point out four advantages of a slider task as a real-effort task compared with other real-effort tasks. First, the slider task is simple to understand and does not require pre-existing knowledge. Second, the slider task is identical every time, unlike solving math problems, negotiating mazes, or solving anagrams. Third, the slider task has little randomness. Fourth, there is no scope for guessing in the slider task.
} 
subjects started into the main part of the slider task and their incomes were determined by their relative performance. ${ }^{10}$

Subjects solved computational questions before the exit survey. Congdon et al. (2011) and Abeler and Jager (2015) showed that cognitive and computational ability are related to tax perceptions. To measure cognitive ability, we used a CRT test (Frederick 2005). ${ }^{1}{ }^{1}$ To identify whether subjects understood the manner of tax calculation, we asked comprehension questions about each tax calculation. One question (TaxQ1) concerned income tax: "If an income tax rate is $20 \%$, which alternative presents the correct answer for calculating the tax owed by someone whose income is $¥ 1$ million?” The other question (TaxQ2) concerned consumption tax: “If a consumption tax rate is $20 \%$, which alternative presents the correct answer for calculating the tax owed by someone whose consumption is $¥ 1$ million?” Subjects chose the following alternatives: " 1 million $\times 20 / 80$," " 1 million $\times 20 / 100$," " 1 million $\times 20 / 120$," and "none of the above." The correct answer for TaxQ1 is " 1 million $\times 20 / 100$." The correct answer for TaxQ2 is " 1 million $\times 20 / 120$."

In the exit survey, we asked subjects hypothetical questions about tax: "Suppose the amounts owed in income tax and consumption tax are equivalent, which tax do you prefer if either must be imposed?" Subjects chose the following alternatives: "I'd like to impose an income tax," "It's indifferent for me," and "I'd like to impose a consumption tax." This hypothetical question can elicit direct preferences without miscalculating the amount of tax owed. In the exit survey, the subjects who chose "I'd like to impose an income tax" were defined as a subject who prefers income tax in the exit survey and those who chose "I'd like to impose a consumption tax" were defined as a subject who prefers consumption tax in the exit survey.

Table 2 shows individual characteristics and computational abilities of subjects. Some characteristics are not balanced between treatments. We will control individual characteristics in the subsequent empirical analysis. About $40 \%$ of subjects calculated all answers correctly in the CRT test, and only $20 \%$ of subjects calculated consumption tax correctly. The proportion of subjects who prefer consumption tax in Random was significantly higher than that of subjects who prefer income tax $(p=0.067)$. The proportion of subjects who prefer consumption tax in Real-effort was slightly higher than that of subjects who prefer income tax, but this finding is not statistically significant ( $p=0.381$ ).

\footnotetext{
10 Before the main part of the slider task, subjects forecast their income rank in the main part.

11 We use three well-known questions. CRT1: A bat and a ball cost $¥ 11,000$. The bat costs $¥ 1,000$ more than the ball. How much does the ball cost? CRT2: If it takes 5 machines 5 minutes to make 5 widgets, how long would it take 100 machines to make 100 widgets? CRT3: In a lake, there is a patch of lily pads. Every day, the patch doubles in size. If it takes 48 days for the patch to cover the entire lake, how long would it take for the patch to cover half of the lake?
} 


\section{Hypotheses}

In this experiment, income $Y$ equals total consumption including tax, $C G$, so that if the amount of income tax is equivalent to the amount of consumption tax, the relationship between the income tax rate $t_{y}$ and the consumption tax rate $t_{c}$ is

$$
t_{y}=\frac{t_{c}}{1+t_{c}}<t_{c} .
$$

Hence, the nominal consumption tax rate is higher than the nominal income tax rate when the consumption tax burden is equivalent to the income tax burden. The $20 \%$ income tax is equivalent to the $25 \%$ consumption tax. The consumption taxes (22\% and $20 \%)$ are less of a burden than the $20 \%$ income tax. Therefore, if subjects can rationally calculate the amount of tax, the hypothesis is as follows:

Hypothesis 1A: Subjects can rationally calculate the amount of tax.

If subjects can rationally calculate the amount of tax, they choose a less burdensome tax system: The 20\% income tax is indifferent to the 25\% consumption tax. Subjects choose the consumption taxes (22\% and 20\%), which are less burdensome than the $20 \%$ income tax.

However, subjects are likely to miscalculate the amount of consumption tax, which suggests that they do not understand the difference between the definitions of consumption tax and income tax. Subjects may not understand that consumption taxes are imposed on the before-tax price. If subjects misunderstand that consumption taxes are imposed on the after-tax price, they evaluate the tax systems on the basis of comparing the nominal tax rates. Therefore, if subjects miscalculate the amount of consumption tax, the behavioral hypothesis is as below:

Hypothesis 1B: Subjects miscalculate consumption taxes.

If subjects calculate the amount of consumption tax like the amount of income tax, they evaluate the tax systems on the basis of comparing the nominal tax rates. Subjects choose the $20 \%$ income tax, which seems to be less burdensome than the consumption taxes (25\% and 22\%). Subjects are indifferent in choosing between the $20 \%$ income tax and $20 \%$ consumption tax.

Blumkin et al. (2012) showed that income and consumption taxes are not equivalent because subjects reduce their effort more in response to income tax than to an equivalent consumption tax. This is because subjects ignore the existence of consumption tax when they provide their effort in the case of imposed consumption tax, though they cognize the existence of income tax when they provide their effort in the case of imposed income tax. Therefore, if we 
get the same result as that of Blumkin et al. (2012), the hypothesis is as below:

Hypothesis 1C: Subjects ignore consumption taxes.

If subjects ignore the consumption tax, they choose the consumption taxes (25\%, 22\%, and $20 \%)$.

Subjects in Blumkin et al.'s (2012) study might have not preferred income tax because income was determined on the basis of their performance of a real-effort task. Durante et al. (2014) showed that subjects support a lower income tax when their incomes are determined on the basis of their performance rather than when their incomes are determined randomly. This result implies that subjects do not prefer income tax when their incomes are determined by their performance of a real-effort task.

Hypothesis 2

Subjects do not prefer income tax when their incomes are determined on the basis of their performance of the real-effort task (Real-effort income group) as opposed to when their incomes are determined randomly (Random income group).

\section{Experimental Results}

In this section, we first show the proportion of each chosen tax to test two hypotheses. Second, we classify subjects based on the tax choice patterns.

\subsection{Tax Choices}

In Table 3, we regress a set of experimental conditions on tax choices. The dependent variable is 1 if a subject chooses an income tax and 0 if a subject chooses a consumption tax. We use a linear probability model with the standard error clustered by subject. When subjects chose between the $20 \%$ income tax and the $25 \%$ consumption tax, $86.8 \%$ chose income tax before their incomes were determined (column 1). There was no difference in preference for tax systems before and after their incomes were determined. Compared with the Random income group, the proportion of subjects choosing income tax in the Real-effort income group was less than 13.7 percent points. The proportion of subjects choosing income tax is significantly higher than $50 \%$ in all cases. This result implies that subjects prefer the $20 \%$ income tax to the $25 \%$ consumption tax, though the amount of the $20 \%$ income tax is equivalent to that of the $25 \%$ consumption tax. The result supports Hypothesis 1B. Subjects do not prefer an income tax that has a higher nominal tax rate than an equivalent income tax because subjects calculate the financial burden of consumption tax in the same way as that for income tax.

When subjects chose between the $20 \%$ income tax and $22 \%$ consumption tax, $71.7 \%$ chose 
income tax before their incomes were determined (column 2 of Table 3). There was no difference in preference for tax systems before and after their incomes were determined. The proportion of subjects choosing income tax was significantly higher than $50 \%$ in all cases. This result implies that subjects prefer the $20 \%$ income tax to the $22 \%$ consumption tax. The result also supports Hypothesis 1B.

When subjects chose between the 20\% income tax and the 20\% consumption tax, $39.6 \%$ chose income tax before their incomes were determined (column 3 of Table 3). There was no difference in preference for tax systems before and after their incomes were determined. Although subjects are indifferent to the choice between income tax and consumption tax before their incomes (Random) are determined, the proportion of subjects choosing income tax is significantly lower than $50 \%$ in other cases. This result implies that subjects tend to prefer the $20 \%$ consumption tax to the $20 \%$ income tax when the nominal tax rates are identical. Under the consumption tax miscalculation bias, the result supports Hypothesis 1C that subjects prefer consumption tax because of the consumption tax ignorance bias.

In the regression in Table 4, we treat parameters of consumption taxes as independent variables and the dependent variable is an income tax choice dummy in the same manner as in Table 3. We control another set of experimental conditions, individual characteristics, and computational abilities on tax choices. Subjects do not prefer the $20 \%$ income tax to the $20 \%$ consumption tax and the $22 \%$ consumption tax compared with the $25 \%$ consumption tax (column 1). Subjects in the Real-effort group do not prefer income tax to consumption tax more than subjects in the Random group. This result supports Hypothesis 2. These results do not change with controlling individual characteristics (column 2). In column 3, we control computational abilities. Subjects who are all correct in CRT questions prefer an income tax over a consumption tax. Even subjects who can correctly answer the CRT questions miscalculate the amount of tax burden. Subjects who are all correct in TaxQs tend to choose the $22 \%$ consumption tax over the $20 \%$ income tax. This result implies that subjects who misunderstand the definition of a consumption tax prefer the $20 \%$ income tax to the $22 \%$ consumption tax, despite the $20 \%$ income tax having higher tax burden than the $22 \%$ consumption tax.

\subsection{Subject types}

Table 5 shows the subject types based on the tax choice patterns. We defined "strong CT lover" as a subject who always chose consumption taxes rather than income tax. We defined "IT lover" as a subject who chose income tax when the tax burdens are equivalent and chose consumption taxes $22 \%$ and $20 \%$ otherwise. We defined "miscalculation biased" as a subject who chose the consumption tax $20 \%$ only when the nominal tax rates are equivalent and chose income tax otherwise. We defined "strong IT lover" as a subject who always chose the 
$20 \%$ income tax rather than consumption taxes. The strong CT lover and the CT lover evaluate the tax systems based on the amount of tax burden, because they choose less tax burden. Such subjects are only one-third. Most subjects have an irrational choice. One-third subjects choose consumption tax if the nominal consumption tax rate is identical to the nominal income tax rate (the miscalculation biased). The strong IT lover implies that these subjects prefer income tax to consumption tax in general. Although subjects seemingly prefer an income tax over a consumption tax when both taxes are equivalent, the proportion preferring an income tax nearly equals that preferring a consumption tax if we assume that subjects with a miscalculation bias prefer a consumption tax when these taxes are equivalent.

Table 6 shows the relationship between subject types and individual characteristics. We use multinomial logit estimation. The figures show the average marginal effect. Subjects who correctly answer the TaxQs are likely to be strong CT lovers or IT lovers. They evaluate tax systems based on their tax burden, because they can calculate it correctly. If tax burdens are equivalent, their choice depends on their individual preferences concerning taxes. A subject who prefers consumption tax in the exit survey, who prefer consumption tax if its burden equals that of an income tax among subjects who cannot correctly answer the TaxQs are likely to be miscalculation biased. This result supports that they prefer the $20 \%$ income tax to the $25 \%$ and $22 \%$ consumption taxes because they do not understand the definition of a consumption tax. A subject who prefers consumption tax in the exit survey among subjects who answer the TaxQs correctly are likely to be the strong CT lovers. They can calculate the tax burden correctly and prefer a consumption tax if amounts owed are equivalent. The table also shows that a subject who prefers consumption tax in the exit survey is likely to be IT lovers and miscalculation biased. This result indicates that some subjects who answered the TaxQs correctly did not understand the calculation at the time of the experiment but understood it in the TaxQs.

\section{Discussion and Conclusion}

We examine whether income and consumption taxes are equivalent throughout a choice experiment. Subjects prefer the $20 \%$ income tax to the $25 \%$ consumption tax where they are equivalent. This result implies that the equivalence between income tax and consumption tax does not hold because of the consumption tax miscalculation bias. Subjects calculate the amount of consumption tax in the same way as an income tax calculation, which implies that subjects mistakenly perceive consumption tax, which has a higher nominal tax rate than income tax, as having a heavier burden. Consequently, subjects prefer the $20 \%$ income tax, which has a lower nominal tax rate than the $25 \%$ consumption tax. Moreover, subjects prefer the $20 \%$ income tax to the $22 \%$ consumption taxes, despite the amount of consumption tax being smaller than the amount of income tax. This result also indicates the existence of the consumption tax 
miscalculation bias. Most subjects cannot correctly calculate the amount of consumption tax. Subjects prefer the $20 \%$ consumption tax to the $20 \%$ income tax when the nominal tax rate is identical. Subjects misunderstand that the amount of consumption tax equals the amount of income tax because subjects miscalculate the amount of consumption tax. If subjects see that the financial burden between the two taxes is equivalent, they prefer consumption tax to income tax. This result is consistent with that of Blumkin et al. (2012) under the tax rate illusion.

In Blumkin et al.'s (2012) and Chetty et al.'s (2009) studies, the misperception of tax results from ignoring consumption tax. In particular, the equivalence between consumption and income taxes is not held by the consumption ignorance bias in Blumkin et al.'s (2012) study. On the other hand, our result implies that consumption and income taxes are not equivalent because people miscalculate the financial burden of consumption tax even if they can take into account consumption tax.

Miscalculation of tax is attributed to an insufficient understanding of tax definitions. Our result implies that people calculate the amount of consumption tax as if it is tax inclusive despite it being tax exclusive, so people miscalculate the amount of consumption tax as they often do not realize it is already included in the prices. In tax reforms of the future, if all notations of taxes were standardized as tax inclusive, people could correctly calculate them. As a result, people could make an unbiased decision. There is a possibility that people miscalculate the amount of tax even if they consider the existence of tax, so that taxes should be presented by the notation of being difficult to miscalculate.

\section{References}

Abeler, J., and Jäger, S. 2015. Complex Tax Incentives. American Economic Journal: Economic Policy, 7(3), 1-28.

Braun, R. A., and Joines, D. H. 2015. The Implications of a Graying Japan for Government Policy. Journal of Economic Dynamics and Control, 57, 1-23.

Bettinger, E. P., Long, B. T., Oreopoulos, P., and Sanbonmatsu, L. 2012. The Role of Application Assistance and Information in College Decisions: Results from the H\&R Block FAFSA Experiment. Quarterly Journal of Economics, 127(3), 1205-1242.

Blumkin, T., Ruffle, B. J., and Ganun, Y. 2012. Are Income and Consumption Taxes Ever Really Equivalent? Evidence from a Real-Effort Experiment with Real Goods. European Economic Review, 56(6), 1200-1219.

Borck, R., Engelmann, D., Müller, W., and Normann, H. T. 2002. Tax Liability-Side Equivalence in Experimental Posted-Offer Markets. Southern Economic Journal, 68(3), 672-682.

Chetty, R., Looney, A., and Kroft, K. 2009. Salience and Taxation: Theory and Evidence. 
American Economic Review, 99(4), 1145-1177.

Chetty, R., and Saez, E. 2013. Teaching the Tax Code: Earnings Responses to an Experiment with EITC Recipients. American Economic Journal: Applied Economics, 5(1), 1-31.

Congdon, W. J., Kling, J. R., and Mullainathan, S. 2011. Policy and Choice: Public Finance Through the Lens of Behavioral Economics. Brookings Institution Press.

de Bartolome, C. A. 1995. Which Tax Rate Do People Use: Average or Marginal? Journal of Public Economics, 56(1), 79-96.

Durante, R., Putterman, L., and Weele, J. 2014. Preferences for Redistribution and Perception of Fairness: An Experimental Study. Journal of the European Economic Association, 12(4), 1059-1086.

Feldman, N. E., and Katuščák, P. 2006. Should the Average Tax Rate be Marginalized? Center for Economic Research and Graduate Education Economics Institute Working Paper 304.

Feldman, N. E., and Ruffle, B. J. 2015. The Impact of Including, Adding, and Subtracting a Tax on Demand. American Economic Journal: Economic Policy, 7(1), 95-118.

Finkelstein, A. 2009. E-ztax: Tax Salience and Tax Rates. Quarterly Journal of Economics, 124(3), 969-1010.

Fischbacher, U. 2007. z-Tree: Zurich Toolbox for Ready-made Economic Experiments. Experimental Economics, 10(2), 171-178.

Frederick, S. 2005. Cognitive reflection and decision making. Journal of Economic Perspectives, 19(4), 25-42.

Gill, D., and Prowse, V. 2012. A Structural Analysis of Disappointment Aversion in a Real Effort Competition. American Economic Review, 102(1), 469-503.

Gill, D., and Prowse, V. 2011. A Novel Computerized Real Effort Task Based on Sliders. Discussion Paper 5022, IZA.

Kachelmeier, S. J., Limberg, S. T., and Schadewald, M. S. 1994. Experimental Evidence of Market Reactions to New Consumption Taxes. Contemporary Accounting Research, 10(2), 505-545.

Kerschbamer, R., and Kirchsteiger, G. 2000. Theoretically Robust but Empirically Invalid? An Experimental Investigation into Tax Equivalence. Economic Theory, 16(3), 719-734.

Liebman, J. B., and Luttmer, E. F. 2011. Would People Behave Differently If They Better Understood Social Security? Evidence from a Field Experiment. National Bureau of Economic Research Working Paper 17287.

Liebman, J. B., and Zeckhauser, R. J. 2004. Schmeduling. Unpublished.

Ruffle, B. J. 2005. Tax and Subsidy Incidence Equivalence Theories: Experimental Evidence from Competitive Markets. Journal of Public Economics, 89(8), 1519-1542.

Sausgruber, R., and Tyran, J. R. 2005. Testing the Mill Hypothesis of Fiscal Illusion. Public 
Choice, 122(1), 39-68.

Sausgruber, R., and Tyran, J. R. 2011. Are We Taxing Ourselves? : How Deliberation and Experience Shape Voting on Taxes. Journal of Public Economics, 95(1), 164-176. 


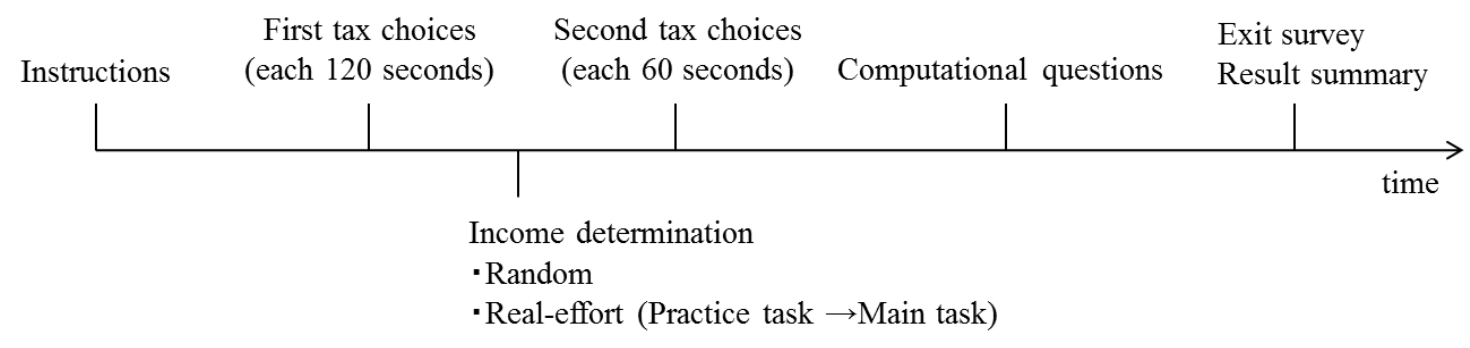

Figure 1 Experimental timeline

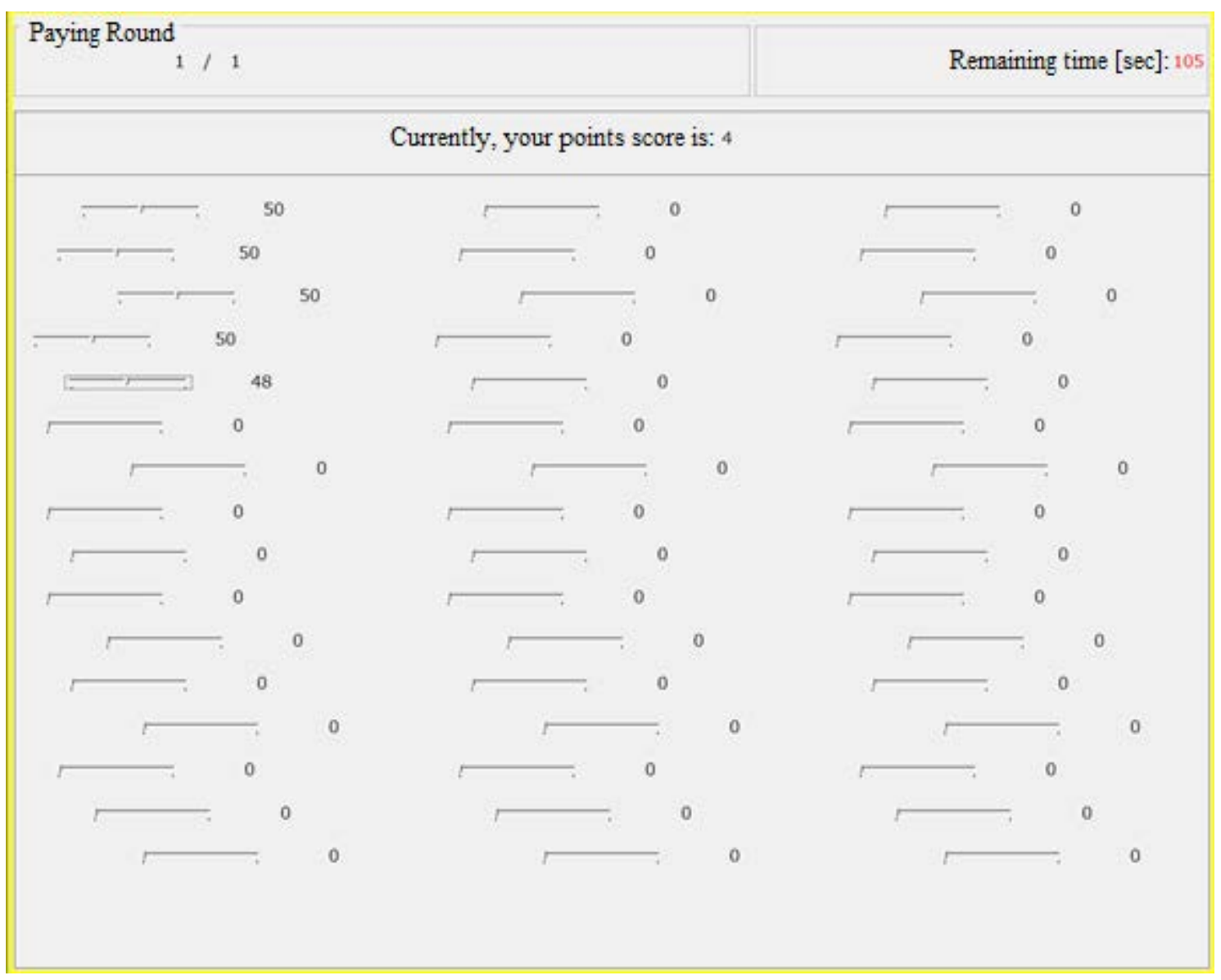

Figure 2 Screen of the slider task 
Table 1 After-tax parameters

\begin{tabular}{|c|c|c|c|}
\hline Tax system [Tax revenue] & & $\begin{array}{c}\text { Income } \\
\text { [After-tax income] }\end{array}$ & $\begin{array}{c}\text { Total consumption } \\
\text { [After-tax consumption] }\end{array}$ \\
\hline \multicolumn{4}{|l|}{$20 \%$ income tax [2780] } \\
\hline & 1st quintile & 1600 [1280] & 1280 \\
\hline & 2nd quintile & 2200 [1760] & 1760 \\
\hline & 3rd quintile & 2500 [2000] & 2000 \\
\hline & 4th quintile & 3100 [2480] & 2480 \\
\hline & 5th quintile & 4500 [3600] & 3600 \\
\hline \multicolumn{4}{|l|}{$25 \%$ consumption tax [2780] } \\
\hline & 1st quintile & 1600 & $1600[1280]$ \\
\hline & 2nd quintile & 2200 & $2200[1760]$ \\
\hline & 3rd quintile & 2500 & 2500 [2000] \\
\hline & 4th quintile & 3100 & 3100 [2480] \\
\hline & 5th quintile & 4500 & $4500[3600]$ \\
\hline \multicolumn{4}{|l|}{$22 \%$ consumption tax [2510] } \\
\hline & 1st quintile & 1600 & $1600[1310]$ \\
\hline & 2nd quintile & 2200 & $2200[1800]$ \\
\hline & 3rd quintile & 2500 & $2500[2050]$ \\
\hline & 4th quintile & 3100 & 3100 [2540] \\
\hline & 5th quintile & 4500 & 4500 [3690] \\
\hline \multicolumn{4}{|l|}{$20 \%$ consumption tax [2320] } \\
\hline & 1st quintile & 1600 & 1600 [1330] \\
\hline & 2nd quintile & 2200 & $2200[1830]$ \\
\hline & 3rd quintile & 2500 & 2500 [2080] \\
\hline & 4th quintile & 3100 & 3100 [2580] \\
\hline & 5th quintile & 4500 & $4500[3750]$ \\
\hline
\end{tabular}


Table 2 Summary statistics of individual characteristics and computational abilities

\begin{tabular}{lccc}
\hline & Random & Real-effort & Difference \\
\hline Age & 22.57 & 21.33 & $1.24 * * *$ \\
Female & $(1.76)$ & $(1.62)$ & $(0.33)$ \\
& 0.38 & 0.38 & -0.01 \\
Undergrad & $(0.49)$ & $(0.49)$ & $(0.10)$ \\
& 0.62 & 0.81 & $-0.19^{* *}$ \\
Economics major & $(0.49)$ & $(0.40)$ & $(0.09)$ \\
& 0.04 & 0.06 & -0.02 \\
Social science major (excl. economics) & $(0.04)$ & $(0.24)$ & $(0.04)$ \\
& 0.23 & 0.13 & 0.09 \\
Engineering major & $(0.42)$ & $(0.34)$ & $(0.08)$ \\
& 0.40 & 0.46 & -0.07 \\
Natural science major & $(0.49)$ & $(0.50)$ & $(0.10)$ \\
Other major & 0.06 & 0.15 & -0.10 \\
& $(0.23)$ & $(0.36)$ & $(0.06)$ \\
CRT all correct & 0.28 & 0.19 & 0.09 \\
TaxQ1 (income tax) correct & $(0.41)$ & $(0.40)$ & $(0.08)$ \\
TaxQ2 (consumption tax) correct & 0.36 & 0.38 & -0.03 \\
TaxQ all correct & $(0.48)$ & $(0.49)$ & $(0.10)$ \\
Subject who prefers income tax in the exit survey & 0.98 & 1.00 & -0.02 \\
Subject who prefers consumption tax in the exit survey & 0.51 & 0.42 & 0.09 \\
& $(0.50)$ & $(0.50)$ & $(0.08)$ \\
\hline Observations & 53 & 52 & \\
\hline
\end{tabular}

Note: “Other major” includes foreign language, health, and humanity majors. 
Table 3 Effects of experimental conditions on preferences for income and consumption taxes

\begin{tabular}{|c|c|c|c|}
\hline & IT $(20 \%)$ or CT $(25 \%)$ & IT $(20 \%)$ or CT $(22 \%)$ & IT $(20 \%)$ or CT $(20 \%)$ \\
\hline & $(1)$ & (2) & (3) \\
\hline \multirow[t]{2}{*}{ After } & 0.038 & 0.075 & -0.019 \\
\hline & $(0.060)$ & $(0.065)$ & $(0.057)$ \\
\hline \multirow[t]{2}{*}{ Slider task } & $-0.137 *$ & -0.082 & -0.031 \\
\hline & $(0.078)$ & $(0.092)$ & $(0.096)$ \\
\hline \multirow[t]{2}{*}{ Slider task $\times$ After } & 0.078 & -0.037 & -0.000 \\
\hline & $(0.080)$ & $(0.094)$ & $(0.091)$ \\
\hline \multirow[t]{2}{*}{ Constant } & $0.868 * * *$ & $0.717^{* * *}$ & $0.396 * * *$ \\
\hline & $(0.047)$ & $(0.063)$ & $(0.068)$ \\
\hline \multirow{2}{*}{ Constant $=0.5$} & $F(1,104)=61.10$ & $\mathrm{~F}(1,104)=12.00$ & $\mathrm{~F}(1,104)=2.33$ \\
\hline & $(p=0.00)$ & $(\mathrm{p}=0.00)$ & $(p=0.13)$ \\
\hline \multirow{2}{*}{ Constant + After $=0.5$} & $F(1,104)=99.66$ & $F(1,104)=26.91$ & $F(1,104)=3.31$ \\
\hline & $(\mathrm{p}=0.00)$ & $(p=0.00)$ & $(p=0.07)$ \\
\hline \multirow{2}{*}{ Constant + Slider task $=0.5$} & $F(1,104)=13.74$ & $F(1,104)=3.97$ & $F(1,104)=3.97$ \\
\hline & $(\mathrm{p}=0.00)$ & $(p=0.05)$ & $(\mathrm{p}=0.05)$ \\
\hline \multirow{2}{*}{ Constant + Slider task + After $=0.5$} & $F(1,104)=9.62$ & $F(1,104)=5.00$ & $F(1,104)=3.00$ \\
\hline & $(\mathrm{p}=0.00)$ & $(\mathrm{p}=0.03)$ & $(\mathrm{p}=0.09)$ \\
\hline Observations & 210 & 210 & 210 \\
\hline Clusters & 105 & 105 & 105 \\
\hline $\mathrm{R}^{2}$ & 0.031 & 0.017 & 0.001 \\
\hline
\end{tabular}

Notes: Dependent variable $=1$ if a subject chooses an income tax (IT). Dependent variable $=0$ if a subject chooses a consumption tax (CT). Standard errors clustered by subject reported in parentheses.

*** Significant at $1 \%$; ** significant at $5 \%$; * significant at $10 \%$. 
Table 4 Effects of experimental conditions and computational abilities

\begin{tabular}{|c|c|c|c|}
\hline \multirow[t]{2}{*}{ Dependent variable: } & \multicolumn{3}{|c|}{ Income tax (1) or consumption tax (0) } \\
\hline & $(1)$ & $(2)$ & (3) \\
\hline Constant (Baseline: CT25) & $\begin{array}{c}0.868 * * * \\
(0.047)\end{array}$ & $\begin{array}{c}2.015^{* * *} \\
(0.515)\end{array}$ & $\begin{array}{c}1.989 * * * \\
(0.492)\end{array}$ \\
\hline CT22 & $\begin{array}{c}-0.151^{* * *} \\
(0.057)\end{array}$ & $\begin{array}{c}-0.151^{* * *} \\
(0.057)\end{array}$ & $\begin{array}{c}-0.132 * * \\
(0.062)\end{array}$ \\
\hline СТ20 & $\begin{array}{c}-0.472 * * * \\
(0.070)\end{array}$ & $\begin{array}{c}-0.472 * * * \\
(0.070)\end{array}$ & $\begin{array}{c}-0.449 * * * \\
(0.078)\end{array}$ \\
\hline After & $\begin{array}{c}0.038 \\
(0.060)\end{array}$ & $\begin{array}{c}0.038 \\
(0.061)\end{array}$ & $\begin{array}{c}0.038 \\
(0.061)\end{array}$ \\
\hline After $\times$ CT22 & $\begin{array}{c}0.038 \\
(0.071)\end{array}$ & $\begin{array}{c}0.038 \\
(0.072)\end{array}$ & $\begin{array}{c}0.038 \\
(0.072)\end{array}$ \\
\hline After $\times$ CT20 & $\begin{array}{c}-0.057 \\
(0.069)\end{array}$ & $\begin{array}{l}-0.057 \\
(0.069)\end{array}$ & $\begin{array}{c}-0.057 \\
(0.069)\end{array}$ \\
\hline Slider task & $\begin{array}{c}-0.137 * \\
(0.078)\end{array}$ & $\begin{array}{c}-0.161^{*} \\
(0.082)\end{array}$ & $\begin{array}{c}-0.150 * \\
(0.077)\end{array}$ \\
\hline Slider task $\times$ CT22 & $\begin{array}{c}0.055 \\
(0.093)\end{array}$ & $\begin{array}{c}0.055 \\
(0.094)\end{array}$ & $\begin{array}{c}0.080 \\
(0.096)\end{array}$ \\
\hline Slider task $\times$ CT20 & $\begin{array}{c}0.106 \\
(0.105)\end{array}$ & $\begin{array}{c}0.106 \\
(0.105)\end{array}$ & $\begin{array}{c}0.119 \\
(0.107)\end{array}$ \\
\hline Slider task $\times$ After & $\begin{array}{c}0.078 \\
(0.080)\end{array}$ & $\begin{array}{c}0.078 \\
(0.081)\end{array}$ & $\begin{array}{c}0.078 \\
(0.081)\end{array}$ \\
\hline After $\times$ Slider task $\times$ CT22 & $\begin{array}{l}-0.115 \\
(0.105)\end{array}$ & $\begin{array}{l}-0.115 \\
(0.106)\end{array}$ & $\begin{array}{l}-0.115 \\
(0.106)\end{array}$ \\
\hline After $\times$ Slider task $\times$ CT20 & $\begin{array}{c}-0.078 \\
(0.111)\end{array}$ & $\begin{array}{l}-0.078 \\
(0.112)\end{array}$ & $\begin{array}{l}-0.078 \\
(0.112)\end{array}$ \\
\hline CRT all correct & & & $\begin{array}{l}0.097 * \\
(0.056)\end{array}$ \\
\hline CRT all correct $\times$ CT22 & & & $\begin{array}{c}0.054 \\
(0.060)\end{array}$ \\
\hline CRT all correct $\times$ CT20 & & & $\begin{array}{l}-0.013 \\
(0.095)\end{array}$ \\
\hline TaxQ all correct & & & $\begin{array}{l}-0.125 \\
(0.084)\end{array}$ \\
\hline TaxQ all correct $\times$ CT22 & & & $\begin{array}{c}-0.224 * * \\
(0.086)\end{array}$ \\
\hline TaxQ all correct $\times$ CT20 & & & $\begin{array}{c}-0.107 \\
(0.105) \\
\end{array}$ \\
\hline Individual controls & No & Yes & Yes \\
\hline Observations & 630 & 630 & 630 \\
\hline Clusters & 105 & 105 & 105 \\
\hline $\mathrm{R}^{2}$ & 0.178 & 0.218 & 0.265 \\
\hline
\end{tabular}

Notes: CT25 is the $25 \%$ consumption tax. CT22 is the $22 \%$ consumption tax. CT20 is the $20 \%$ consumption tax. Standard errors clustered by subject reported in parenthesis.

*** Significant at $1 \%$; ** significant at $5 \%$; * significant at $10 \%$. 
Table 5 Subject type

\begin{tabular}{r|rrrrr} 
& Strong CT lover & IT lover & Miscalculation biased & Strong IT lover & Others \\
\hline Income (Random) & & & & & \\
Before & $11.3 \%$ & $13.2 \%$ & $34.0 \%$ & $35.8 \%$ & $5.7 \%$ \\
After & $9.4 \%$ & $11.3 \%$ & $41.5 \%$ & $37.7 \%$ & $0.0 \%$ \\
Income (Real-effort) & & & & & \\
Before & $17.3 \%$ & $15.4 \%$ & $25.0 \%$ & $28.8 \%$ & $13.5 \%$ \\
After & $15.4 \%$ & $17.3 \%$ & $32.7 \%$ & $34.6 \%$ & $0.0 \%$
\end{tabular}

Notes: Strong CT lover is a subject who always chooses consumption taxes rather than income tax. IT lover is a subject who chooses income tax only when the tax burdens are equivalent and choses consumption taxes $22 \%$ and $20 \%$ otherwise. Miscalculation biased is a subject who chooses the $20 \%$ consumption tax when the nominal tax rates are equivalent and income tax otherwise. Strong IT lover is a subject who always chooses the $20 \%$ income tax rather than consumption taxes.

Table 6 Effect of computational abilities and direct tax preference on subject type

\begin{tabular}{lcccc}
\hline & $\begin{array}{c}\text { Strong CT lover } \\
(1)\end{array}$ & IT lover & Miscalculation biased & Strong IT lover \\
& $0.350^{* * *}$ & $0.250^{* *}$ & $(3)$ & $(4)$ \\
\hline TaxQ all correct & $(0.124)$ & $(0.099)$ & -0.115 & 0.045 \\
& 0.074 & -0.036 & $0.231)$ & $(0.185)$ \\
Prefer IT in the exit survey & $(0.087)$ & $(0.092)$ & $(0.083$ & -0.073 \\
& 0.086 & 0.025 & $0.268^{* * *}$ & $(0.094)$ \\
Prefer CT in the exit survey & $(0.076)$ & $(0.077)$ & $(0.105)$ & $-0.238^{* * *}$ \\
& $-0.280^{*}$ & -0.069 & 0.272 & $(0.091)$ \\
Prefer IT $\times$ TaxQ all correct & $(0.145)$ & $(0.129)$ & $(0.268)$ & 0.028 \\
& $0.290^{*}$ & $0.515^{* * *}$ & $1.744^{* * *}$ & $(0.219)$ \\
Prefer CT $\times$ TaxQ all correct & $(0.166)$ & $(0.169)$ & $(0.304)$ & $\left(0.315^{* * *}\right.$ \\
& & & & \\
\hline
\end{tabular}

Notes: Experimental conditions and individual characteristics are also controlled. Figures report average marginal effects. Standard errors are calculated by delta-method.

*** Significant at $1 \%$;** significant at $5 \%$; * significant at $10 \%$. 


\section{Appendix: Instructions (translated from Japanese)}

\section{Experimental Contents}

In this experiment, you choose a "tax system" in a hypothetical world. The "tax" in this experiment is not the real tax that is imposed on payment but a hypothetical tax.

First, your "income" is determined by a method (as described herein). The "income" is assigned to five income ranks (1600, 2200, 2500, 3100, and 4500 points). In responding to an "income," the amount of "consumption" is automatically determined. The set of "income" and "consumption” is as below:

\begin{tabular}{|l|l|l|l|l|l|}
\hline Income (points) & 1600 & 2200 & 2500 & 3100 & 4500 \\
\hline Consumption (points) & 1600 & 2200 & 2500 & 3100 & 4500 \\
\hline
\end{tabular}

However, a "tax" is imposed on this "income" and "consumption." The effective "tax" depends on your choice (as described herein). A "tax" is of two types. The example tax rate is just an example and may be different from the experimental tax rate. The taxed point under 10 points is rounded off.

\section{Income tax}

An income tax is a tax in proportion to income. For example, if the income tax rate is $10 \%$, your income reduces by $10 \%$. Your consumption also reduces the same proportion in responding to your income. In other words, if the income tax rate is $10 \%$, the consumption is also reduced by $10 \%$.

\section{Consumption tax}

A consumption tax is a tax in proportion to consumptions, and the tax-inclusive amount of consumption does not change even if the consumption tax is imposed; the net (substantial) consumption is found by subtracting the amount of taxation from consumption in responding to the income.

We converted the after-tax total consumption into your payment ( 1 point $=¥ 1)$.

- "Income” determination for Random group [Real-effort group]

The "income" is randomly assigned to five income ranks (each $20 \%$ probability) by a computer. 
The number of subjects is evenly assigned to the five income ranks.

[The "income" is determined on the basis of your performance of a "slider task." We explain later the slider task and your income in detail.]

- Effective "tax system" determination

In this experiment, each person chooses a tax between two options multiple times before and after your income is determined. One tax choice for each person is randomly selected and the tax is imposed on your payment

\section{Experimental Procedure}

This experiment is conducted using a computer. Please follow the directions of the computer. Mind the time restriction.

1. “Tax” choice (before your income is determined)

You choose a tax between two options. After choosing one option, you press the OK button. The

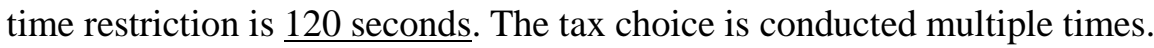

2. Income determination

Your income is determined randomly [on the basis of your performance of a task]. Please confirm your income displayed in front of you.

3. "Tax" choice (after your income is determined)

You choose a tax between two options. After choosing one option, you press the OK button. The

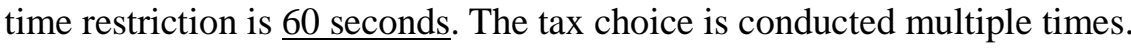

4. Calculation of after-tax income and consumption

First, one tax choice for each person is randomly selected and the tax is imposed on your payment. Please confirm after-tax income and consumption.

After checking your payment, please answer a survey. 


\section{Explanation of a Slider Task}

In this task, there are 48 sliders on your screen, as in the below figure. By using the mouse, you adjust the slider to the position at 50 as much as possible. The time restriction is 120 seconds.

Each slider is positioned at 0 at the first time and you can move each slider to 100. Each value of the slider is displayed at the right of each slider. By using the mouse, you adjust the sliders. You can adjust the position of each slider as many times as you want. Your point in this task is the number of the slider positioned at 50 at the end of the task.

You practice the slider task twice before you move on to the main part of the task.

\section{Income determination}

Your income is determined on the basis of your relative performance of a slider task. The better you perform, the more income you can get. The number of subjects is evenly assigned to the five income ranks. For example, if the number of participants is 20, 4 people are assigned to each income rank.

\section{Experimental procedure}

1. Practice task (120 seconds $\times 2$ )

You practice the slider task twice. This task does not determine your income rank.

\section{Forecasting income rank task}

You forecast your income rank on the main part of the slider task before moving on to the main part. Please choose an income rank that likely to be assigned.

\section{Main task (120 seconds)}

You try the main part of the slider task. The time restriction is 120 seconds.

\section{Result summary}

Please confirm your income. 
Figure Screen of the slider task

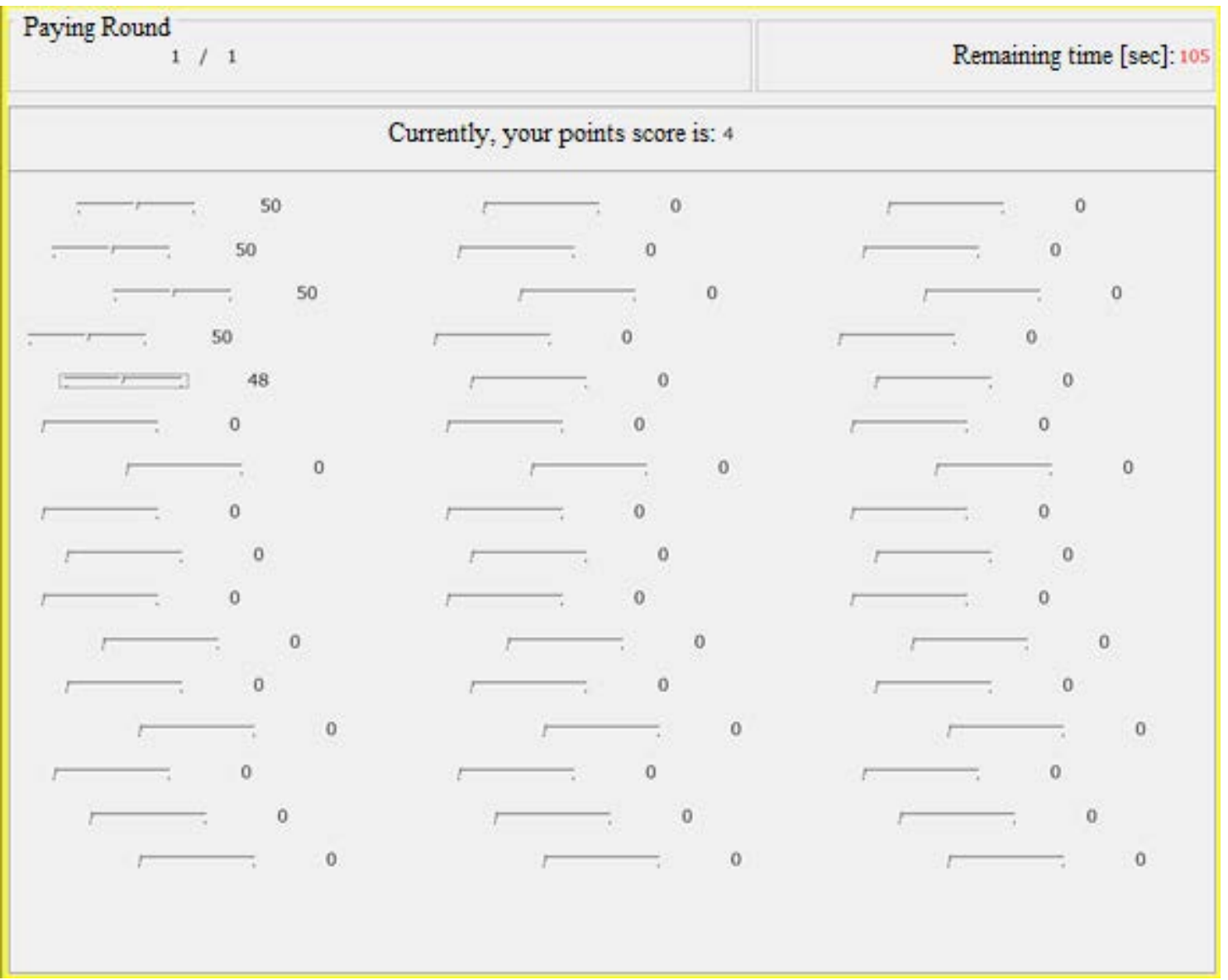

